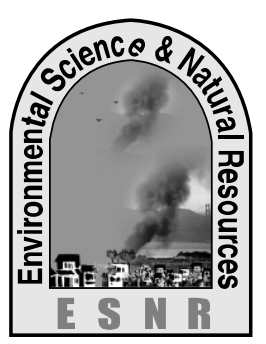

\title{
Credit Facilities in Groundnut Production and its Impact on Poverty Reduction- A Farm Level Survey in Mymensingh District
}

\author{
J. R. Sarker ${ }^{1 *}$, S. Akhter ${ }^{2}$ and M. Jahan ${ }^{1}$
}

${ }^{1}$ Dept. of Agricultural Economics, Bangabandhu Sheikh Mujibur Rahman Agricultural

University, Gazipur, Bangladesh

${ }^{2}$ Department of Development and Poverty Studies, Sher-e-Bangla Agricultural University, Sher-e-Bangla Nagar, Dhaka-1207, Bangladesh

*Corresponding author: jaba.rani@yahoo.com

\begin{abstract}
A study was conducted to determine the poverty and credit facilities of groundnut producers and profitability and resource use efficiency of groundnut production in the selected char areas of Gaffargaon upazila in Mymensingh district. In this study, 100 respondents were randomly selected from the mentioned upazila. Farmers were classified into three categories on the basis of loan size. Cobb-Douglas production function was used to determine the contribution of factors to groundnut yield. It is evident from the study that per acre net returns were greatly influenced by the use of human labour, animal labour, seeds and insecticides and it was found that they got profit from groundnut cultivation and the undiscounted BCRs (both the variable cost and total cost basis) was estimated at 1.88 in case of all categories of farmers. The mentioned factors were directly or jointly responsible for influencing per acre net returns for groundnut cultivation. Maximum loan money was utilized in family expenditure purpose for meeting their emergency and urgent needs to survive. But their repayment was satisfactory. However some problems were identified (i.e, tips and bribes, delay in providing loan and their poverty) in receiving loan for groundnut cultivation. It appears from the analysis that among three categories of farmers marginal farmers suffered a lot from inadequate supply of credit. The present study suggests that to develop agriculture, to reduce poverty and to increase the productivity of the farmers, both public and private sectors need to give attention on groundnut production in char area for their poverty reduction.
\end{abstract}

Key words: Char area, Credit, Groundnut production, Poverty reduction

\section{Introduction}

Groundnut (Arachis hypogaea L.), one of the principal economic crop of world occupies $13^{\text {th }}$ position among fruit crops (Varnell and Mccloud, 1975), $4^{\text {th }}$ place among the oilseed crops in respect to both area and production next to soybean, sunflower and cotton (Weiss, 1983). Groundnuts are one of the major oilseed crops of Bangladesh, but yields of groundnuts are lower in Bangladesh compared to the world average, with the result that Bangladesh produces only about 40 percent of its domestic oil consumption. Groundnut is the second major oil seed crops in Bangladesh covering an area of 0.076 million ha producing 1.2 million MT of nuts. Increase in the production of this crop can help to minimize the shortage of edible oil in the country. It is the richest plant source of thiamin (B1). Groundnut contains at least 13 different types of vitamins and also rich in 26 essential minerals. Incidence of disease is the most important obstacle for groundnut production. Groundnut is an important oilseed crop in Bangladesh on the basis of both in acreage and annual production (Biswas et al,. 2000; Mondal and Wahhab, 2001.) Its cultivation covered about 0.087 million ha and produced about 1.25 million MT of seeds during 201112 (Krishi Diary, 2013). Groundnuts are mostly used as ingredients for a number of industrially processed foods and contribute little to oil production. Groundnut is a major crop in the char lands of Bangladesh, but because of poor yields, farmers derive a limited income from the crop. The objectives of the research are to estimate the profitability of groundnut and resource use efficiency, to determine the credit utilization patterns, to calculate cost and return of groundnut production and to identify the problems of groundnut production and suggest measures for improvement. The production of groundnut is fluctuated more or less in every year
(BBS, 2012). Sometimes it became more than previous year and sometimes it became less. In the year of 2007 08 the area and production of groundnut was 1102 acre and 568 metric ton respectively. But during 2011-2012, the area was declined to 976 and there was a little bit declining in production (521 metric ton) compared to area. One of the major constraints to the successful groundnut production in Bangladesh is the damage caused by insect and mite pests (Biswas et al., 2000). Studies reveal that $15-20$ percent of the total oilseed production is lost directly or indirectly by the attack of insect and mite pests every year (Biswas and Das, 2011). From World Bank, WFP, BBS, 2014, we can be observed that Mymensingh district rank the $6^{\text {th }}$ position on the basis of Head Count Poverty rate. So it is very necessary to provide attention on Mymensingh district basically char area to reduce poverty. According to the estimate half of the districts have poverty rates greater than the national average of 31.4 percent suggesting a high degree of disparity among districts in terms of poverty measures (i.e. as many as 32 districts out 64 districts have higher poverty rate than that of the national poverty rate). Though area and production of groundnut is going down day by day, most of the rural people are dependent on groundnut cultivation for their poverty reduction as they live in char area. Groundnut is one of the major crops in char area. Therefore, the objectives were, To determine the poverty and credit facilities of groundnut producers and profitability and resource use efficiency of groundnut production in the selected study area; To examine how poverty of target farmers could be alleviated through improved cultivation of groundnut production, and To identify farmers attitude towards groundnut cultivation in the study area. 


\section{Materials and Methods}

\section{Data and survey}

Primary data were collected through a farm level survey. A Multi-stage sampling technique was employed for this purpose. In the first stage, Mymensingh district of Bangladesh was purposively selected. Then, from this district the top groundnut producing upazila named as Gaffargaon upazila and from the selected upazila two top groundnut producing villages namely char algi and panchpy were purposively selected. The study purposively focused on extensively groundnut growing areas since groundnut is not grown all over the country. Moreover, programmes for popularizing modern groundnut varieties are more likely to be successful in these areas. In the final stage, 50 groundnut growers were selected randomly from each village using a list of groundnut growers available from the concerned agricultural extension office. Thus, a total of 100 groundnut farmers belonging to two villages were selected as sample of the study and accordingly following structured interview schedule. Farmers were classified into three categories on the basis of loan size, namely category A (having loan below Tk. 5000), category B (having loan within Tk.5,000 to 10,000) and category $\mathrm{C}$ (having loan above Tk. 10,000).

\section{Empirical analysis}

The analysis of data was based on tabular and descriptive techniques. In this research, tabular technique was applied for the analysis of data using simple statistical tools like averages and percentages. The following formula was use for analysis of data in the study areas. Higher production and profit are the two most important factors to motivate farmers towards any new technology. A detailed cost-benefit analysis was calculated for groundnut farmers using tabular analyses techniques. The gross revenue of groundnut is likely to be influenced by different factors, such as the cost of human labour, seed, and chemical fertilizer. The following Cobb-Douglas production function was used to estimate the parameters. The Cobb-Douglas Production function equation was as follows:

$\mathrm{Y}=\mathrm{aX}{ }_{1}^{\mathrm{bi}} \mathrm{X}_{2}^{\mathrm{b} 2} \mathrm{X}_{3}^{\mathrm{b} 3} \mathrm{X}_{4}^{\mathrm{b} 4} \mathrm{X}_{5}^{\mathrm{b} 5} \mathrm{X}_{6}^{\mathrm{b} 6} \mathrm{U}$

By taking $\log$ on both sides the Cobb-Douglas production function was transformed in to the following logarithmic form because it could be solved by ordinary least squares (OLS) method, i.e.

$\log Y=\log a+b_{1} \log X_{1}-\ldots$ $\log \mathrm{Xn}+\mathrm{e}^{\mathrm{ui}}$

The empirical production function was the following $\log Y=\log +b_{1} \log X_{1}+b_{2} \log X_{2}+b_{3} \quad \log X_{3}+b_{4}$ $\log X_{4}+b_{5} \log X_{4}+b_{5} \log X_{5}+U i$

Where, $\mathrm{Y}=$ Yield $(\mathrm{Kg} / \mathrm{acre})$

$\mathrm{X}_{1}=$ No. of human labor (man-day/acre)

$\mathrm{X}_{2}=$ Animal labor $(\mathrm{Tk} / \mathrm{acre})$

$\mathrm{X}_{3}=$ Amount of seed (Kg/acre)

$\mathrm{X}_{4}=$ Amount of manure $(\mathrm{Kg} / \mathrm{acre})$

$\mathrm{X}_{5}=$ Cost of insecticides (Tk/acre)

$\mathrm{a}=$ constant value and $b_{1}, b_{2} \ldots \ldots \ldots \ldots b_{5}=$ Co-efficient of the respective variables and

$\mathrm{Ui}=$ Error term

\section{Results and Discussion}

Result showed that groundnut farmers borrow money from Banks, NGOs and different money markets to meet their financial needs for different farm activities. It is very difficult to assess credit need of the farmers. Table 1 shows the adequacy of credit in the study area. The table indicates the average amount of loan received and percentage of loan received in relation to amount applied for is categorized according to loan received by $\mathrm{A}, \mathrm{B}$ and $\mathrm{C}$ categories which were 72,74 and 70 percent respectively. It also reveals that the farmers in general, received 75 percent of the loan amount applied for. Average amount of loan applied for was found to be Tk. 21808 whereas the average amount received was Tk. 16348 taking all surveyed families together. Approximately, 23 days were required to get loan from different Banks during the study year. Actual time by the $\mathrm{A}, \mathrm{B}$ and $\mathrm{C}$ categories farmers were 27,23 and 20 days which indicates that the category $\mathrm{C}$ got loan within shorter period of time compared to other two categories of farmers possible because of their relatively easy access to the bank officials.

Table 1. Adequacy and time required to receive credit

\begin{tabular}{|c|c|c|c|c|}
\hline $\begin{array}{c}\text { Farmers' } \\
\text { categories }\end{array}$ & $\begin{array}{c}\text { Average } \\
\text { amount } \\
\text { applied } \\
\text { for } \\
\text { (Tk.) }\end{array}$ & $\begin{array}{c}\text { Average } \\
\text { amount } \\
\text { received } \\
\text { (Tk.) }\end{array}$ & $\begin{array}{c}\text { Amount } \\
\text { received } \\
\text { of } \\
\text { applied } \\
\text { for (\%) }\end{array}$ & $\begin{array}{c}\text { Average } \\
\text { days } \\
\text { required } \\
\text { for } \\
\text { receiving } \\
\text { loan }\end{array}$ \\
\hline A & 4544 & 3290 & 72 & 27 \\
\hline B & 7011 & 5182 & 74 & 23 \\
\hline C & 11253 & 7876 & 70 & 20 \\
\hline All & 21808 & 16348 & 75 & 23 \\
\hline
\end{tabular}

source: field survey. 2012

It was difficult to collect information on utilization pattern of credit because most of the borrower farmers kept no research of their transactions made during the year. The borrowers have spent their loaned money on the following categories:
i) Capital expenditure on farming;
ii) Current expenditure on farming;
iii) Non-farm business expenditure; and
iv) Family expenditure.

The main item of family expenditure was repayment of old debt (it means paying back part or whole of outstanding loan to all sources such as money lender, friends and relatives, banks etc.) which alone accounted for 11.75 percent of total loan. They were found with the percent of loan used to repay old debt. Table 2 indicates that there was an inverse relationship between farm size and repayment of old debt. Social ceremony is next prior to family expenditure which alone accounted for 1.97 percent of total loan. 
Table 2. Utilization of loan according to farm size

\begin{tabular}{|c|c|c|c|c|}
\hline \multirow{2}{*}{ Head of expenditure } & \multicolumn{4}{|c|}{ Percentage use of credit } \\
\hline & Category A & Category B & Category $\mathbf{C}$ & All \\
\hline 1. Purchase of land & - & 5.33 & 6.37 & 3.90 \\
\hline 2. Purchases of poultry & 2.38 & 2.30 & 2.98 & 3.83 \\
\hline 3. Payment of rent & 11.31 & 12.63 & 13.81 & 12.58 \\
\hline 4. Release of mortgaged out land & 2.10 & 9.47 & 10.03 & 7.20 \\
\hline Total capital expenditure on farming & 15.79 & 29.73 & 33.19 & 26.23 \\
\hline 5. Land preparation & 4.35 & 4.21 & 6.08 & 4.88 \\
\hline 6. Purchase of seed & 10.46 & 8.37 & 10.83 & 9.89 \\
\hline 7. Purchase of manure & 1.36 & 0.63 & 1.92 & 1.30 \\
\hline 8. Charge for human labour & 5.81 & 5.31 & 5.37 & 5.49 \\
\hline 9. Charge for animal labour & 2.78 & 2.02 & 2.51 & 2.43 \\
\hline 10. Purchase of equipment & 3.04 & 2.06 & 2.37 & 2.49 \\
\hline Total current expenditure on farming & 27.80 & 22.60 & 29.08 & 26.49 \\
\hline Non farm business expenditure & 14.79 & 7.90 & 7.37 & 10.02 \\
\hline 11. Purchases of food & 10.27 & 4.76 & 3.75 & 6.20 \\
\hline 12. Purchase of clothes & 3.91 & 3.33 & 2.09 & 3.11 \\
\hline 13. Educational expenses & 6.09 & 6.67 & 6.81 & 6.52 \\
\hline 14. Medical treatment & 1.89 & 2.17 & 5.57 & 1.87 \\
\hline 15. Repayment of old debt & 10.29 & 13.16 & 11.91 & 11.75 \\
\hline 16. Repairing of house & 7.39 & 6.56 & 3.39 & 5.78 \\
\hline 17. Social ceremonies & 1.78 & 3.12 & 1.02 & 1.97 \\
\hline Total family expenditure & 41.62 & 39.77 & 30.36 & 37.25 \\
\hline Grand total & 100 & 100 & 100 & 100 \\
\hline
\end{tabular}

source: field survey, 2012

Purchase of food in another item of family expenditure which amounted about 6.20 percent of total loan. Cost like this was considered to be emergency food purchase. The farmers were found 2). Cost incurred for purchase of clothes, medical treatment and educational expenses was $3.11,1.87$ and 6.52 percent respectively of the total loaned money.

Table 3 shows the repayment of credit from the different banks by the selected respondents. Repayment capacity is one of the crucial aspects of credit analysis and proper utilization of credit is supposed to have a great influence upon the repayment capacity of the respondents. The average amount received by the category A was Tk. 4290 and at 8 percent interest rate the interest amount was 365 and total repayment was 4655 (Table 3). So, the percent of total repayment was 100 percent. In case of category B principal amount was Tk. 7185, interest was Tk. 514 and total repayment was Tk. 7699 and repayment was also 100 percent. It is evident from the table that the repayment was made by the category A, B and C were 100 percent and repayment percentage was also highly satisfactory (100 percent).
Table 3. Repayment of loan according to farm size

\begin{tabular}{|c|c|c|c|c|}
\hline \multirow{2}{*}{$\begin{array}{c}\text { Farm } \\
\text { size }\end{array}$} & \multicolumn{3}{|c|}{ Average amount repaid } & \multirow{2}{*}{$\begin{array}{c}\text { Percent of } \\
\text { total } \\
\text { repayment }\end{array}$} \\
\hline & $\begin{array}{c}\text { Princi } \\
\text { pal }\end{array}$ & $\begin{array}{c}\text { Intere } \\
\text { st }\end{array}$ & Total & \\
\hline $\begin{array}{c}\text { Category } \\
\text { A }\end{array}$ & 4290 & 365 & 4655 & 100 \\
\hline $\begin{array}{c}\text { Category } \\
\text { B }\end{array}$ & 7185 & 514 & 7699 & 100 \\
\hline $\begin{array}{c}\text { Category } \\
\text { C }\end{array}$ & 12000 & 830 & 12830 & 100 \\
\hline Total & 23475 & 1709 & 25184 & 100 \\
\hline
\end{tabular}
source: field survey, 2012

The main objective of this study was to examine how poverty of target farmers could be alleviated through improved cultivation of groundnut production. This suggests that the increased profitability of groundnut production is a key component of poverty mitigation programme for these people. Therefore, the information provided by the present study is critically important.

\section{Cost and return of groundnut cultivation}

Estimate of cost was exclusively necessary for enterprise costing and subsequently determining the profitability of the enterprise from the point of view of 
farmers. Farmers' decision about production is mainly influenced by the cost of inputs. Farmers used purchased inputs as well as home supplied ones. Purchased inputs such as manure, seed, hired labour, etc. involved out of pocket or direct expenses and it was easy to price these inputs by using the prevailing market price or actual cost of the relevant inputs. The cost items in production were classified under the following heads. Variable costs include human labour, animal labour, seed, manure and insecticides. Fixed costs include land use cost and interest on operating capital.

Table 4 . Per acre costs and returns

\begin{tabular}{|c|c|c|c|c|}
\hline Items & Unit & Quantity & Price/Unit (Tk.) & Total value (Tk.) \\
\hline i) Main product & $\mathrm{Kg}$ & 815 & 40 & 32600 \\
\hline ii) By product & $\mathrm{Kg}$ & 125 & 12 & 1500 \\
\hline A. Gross return $(\mathbf{i}+\mathbf{i i})$ & & & & 34100 \\
\hline \multicolumn{5}{|l|}{ Variable cost: } \\
\hline Family labour & Man-day & 18 & 120 & 2160 \\
\hline Hired labour & Man-day & 15 & 150 & 2250 \\
\hline Total labour & & & & 4410 \\
\hline Draught/Animal labor & Pair/day & 2 & 200 & 400 \\
\hline Seeds & $\mathrm{Kg}$ & 37 & 90 & 3330 \\
\hline Manure - Cow dung & $\mathrm{Kg}$ & 100 & 2 & 200 \\
\hline Insecticides & - & - & & 1000 \\
\hline B. Total variable cost & & & & 9340 \\
\hline \multicolumn{5}{|l|}{ Fixed cost } \\
\hline Land use cost & Decimal & 52.84 & & 5284 \\
\hline Interest on operating capital & Tk. & & & 3470 \\
\hline C. Total fixed cost & Tk. & & & 8754 \\
\hline D. Gross cost $(\mathrm{B}+\mathrm{C})$ & Tk. & & & 18094 \\
\hline E. Gross margin (A-B) & Tk. & & & 24760 \\
\hline F. Net return(A-D) & Tk. & & & 16006 \\
\hline $\begin{array}{l}\text { Benefit cost ratio (A/D) } \\
\text { (undiscounted) }\end{array}$ & - & & & 1.88 \\
\hline
\end{tabular}

source: field survey, 2012

The cost of groundnut production included different variable and fixed costs. It is found from the Table 4 that human labour cost was the major cost item in groundnut production. It is estimated that the production cost of groundnut was Tk. 18094 per acre for the research area. Cost of seed is Tk. 3330 per acre in the char area for groundnut cultivation. Only compost was used as a fertilizer for groundnut cultivation. Total variable cost was Tk. 9430 per acre the study area. Net return from groundnut found Tk. 16006 from the above calculation.

The cost of land use may be estimated by using any of the following concepts.

a) Interest on value of land

b) Valuation of land at its rented value

c) Foregoing income from alternative use

The following formula was used

Interest on operating capital = $\frac{\text { Total variable cost }+ \text { land use cost } \times \text { interest rate } \times \text { time }}{2}$

Calculation of profit was determined by deducting the total cost from gross return

Profit, $\Pi=$ GR - TC

Where, $\Pi=$ Profit, GR $=$ Gross Return, $\mathrm{TC}=$ Total Cost

Benefit cost ratio was measured to see the efficiency of resource use which was applied in the present study. Table 5 shows the estimated benefit cost ratio was 1.88 for groundnut. An attempt has been made to identify and evaluate the effects of some factors of production on gross return of groundnut production. For this purpose, Cobb-Douglas production function has been chosen because of its superior properties, particularly in explaining agricultural production behaviour.

\section{Factors affecting groundnut production}

Considering the importance of the inputs affecting groundnut production, a number of inputs such as human labour, animal labour, seeds, manure and insecticides were considered explanatory variables. The individual effects of these inputs on the dependent variable can be explained to a certain degree by multiple regression analysis.

\section{Model specification for analysis}

To explore the input-output relationship of groundnut production, the Cobb-Douglas form of production function model in its stochastic form was expressed as: $\mathrm{Y}=\mathrm{ax}_{1}{ }_{1}^{\mathrm{b}} \mathrm{ax}_{2}{ }_{2} \mathrm{ax}_{3}{ }_{3} \mathrm{ax}_{4}{ }_{4} \mathrm{ax}_{5}{ }_{5} \mathrm{U}$

Where,

$\mathrm{Y}=$ Gross return $\left(\right.$ Tk.acre $\left.{ }^{-1}\right)$

$\mathrm{X}_{1}=$ Costs of human labour $\left(\right.$ Tk.acre $\left.{ }^{-1}\right)$

$\mathrm{X}_{2}=$ Costs of animal labor $\left(\right.$ Tk.acre $\left.{ }^{-1}\right)$

$\mathrm{X}_{3}=$ Costs of seeds $\left(\right.$ Tk. acre $\left.^{-1}\right)$

$\mathrm{X}_{4}=$ Costs of manure $\left(\right.$ Tk.acre $\left.{ }^{-1}\right)$

$\mathrm{X}_{5}=$ Costs of insecticides $\left(\right.$ Tk.acre $\left.{ }^{-1}\right)$ 
$\mathrm{a}=$ Constant/intercept

The Cobb-Douglas production function was linearized by transforming it into the following double log from so that it could be solved by the least square method:

In $Y=$ Ina $+b_{1} \operatorname{InX}_{1}+b_{2} \operatorname{In} X_{2}+b_{3} \operatorname{In} X_{4}+b_{4} \operatorname{In} X_{4}+b_{5} \operatorname{In} X_{5}+$ $\mathrm{U}$

\section{Explanation of the Estimated Results}

A series of specifications of the model were tried to check for the sign and magnitudes of the coefficients, adjusted $\mathrm{R}^{2}$ and $\mathrm{F}$ - values. Finally the best fit models were selected for estimation and interpretation of the

Table 5. Estimation valuesof coefficient and related statistics of Cobb- Douglas production function of groundnut farms

\begin{tabular}{|c|c|c|}
\hline $\begin{array}{c}\text { Explanatory } \\
\text { variables }\end{array}$ & $\begin{array}{c}\text { Values of } \\
\text { coefficient }\end{array}$ & t-value \\
\hline Intercepts & 2.130 & 2.530 \\
\hline $\begin{array}{c}\text { Human labour } \\
\left(\mathrm{X}_{1}\right)\end{array}$ & $0.453^{* *}$ & 2.130 \\
\hline $\begin{array}{c}\text { Animal } \\
\text { labour }\left(\mathrm{X}_{2}\right)\end{array}$ & $0.374^{* * *}$ & 1.870 \\
\hline Seeds $\left(\mathrm{X}_{3}\right)$ & $0.138^{*}$ & 3.214 \\
\hline Manure$\left(\mathrm{X}_{4}\right)$ & $0.332^{*}$ & 4.501 \\
\hline Insecticides $\left(\mathrm{X}_{5}\right)$ & $0.287^{*}$ & 3.691 \\
\hline $\mathrm{R}^{2}$ & \multicolumn{2}{|c|}{0.781} \\
\hline Adjusted $\mathrm{R}^{2}$ & .0790 \\
\hline F-value & \multicolumn{2}{|c|}{1.29 .061} \\
\hline $\begin{array}{c}\text { Returns to } \\
\text { scale }\left(\sum \text { bi) }\right.\end{array}$ & \multicolumn{2}{|c|}{100} \\
\hline Sample size & \multicolumn{2}{|c|}{} \\
\hline
\end{tabular}

source: field survey, 2012

note: *significant at 1 percent level

$* *$ significant at 5 percent level

$* * *$ significant at 10 percent level

Thus 1 percent increase in animal labour cost would increase gross returns by 0.374 percent. The estimated coefficient of seed cost was which was 0.138 , positive and highly significant at 1 percent level. It reveals that keeping other factors constant, 1 percent increase in seed cost would increase gross return by 0.138 percent. The value of estimated coefficient of manure was 0.332 , which was positive and statistically significant at 1 percent level. It indicates that holding other inputs constant, 1 percent increase in manure cost would increase gross returns by 0.332 percent. The estimated coefficient of insecticides cost was 0.287 indicating keeping other factors constant, 1 percent increase in insecticides cost would increase gross returns by 0.287 percent. However the coefficient was statistically significant at 1 percent level.

\section{Farmers' attitudes toward groundnut cultivation}

The groundnut cultivating farmers were asked to mention the possibility of expanding their cultivated area for groundnut production. About 44 percent farmers indicated that they would increase groundnut area in the next year due to various advantages (Table $6)$. results. The estimated values of the co-coefficients and related statistics of the Cobb-Douglas production function of groundnut as shown in Table 5. The calculated regression coefficient of human labour cost was 0.453 indicating the positive effect of money spent on human labour, keeping other factors constant, would result in an increase of gross return by 0.453 percent at 5 percent level of significant and animal labour cost was 0.374 , which was positive and statistically significant at 10 percent level.

Table 6. Farmers' attitudes towards increase in groundnut cultivation

\begin{tabular}{|l|c|}
\hline \multicolumn{1}{|c|}{ Particulars } & $\begin{array}{c}\text { \% of groundnut } \\
\text { farmers' responded }\end{array}$ \\
\hline A. Willingness to increase & \\
\hline 1. Willing to increase & 44 \\
\hline 2. Not increase & 56 \\
\hline B. Reasons for increasing & \\
\hline 1. Profitable crop & 42 \\
\hline 2. Short duration crop & 47 \\
\hline 3. Less production cost & 61 \\
\hline 4. Higher yield & 50 \\
\hline 5. Meeting household demand & 11 \\
\hline 6. Multi purpose use of oil cake & 27 \\
\hline 7. Good marketing facility & 87 \\
\hline C. Reasons for not increasing & \\
\hline $\begin{array}{c}\text { 1. Lack of enough land for } \\
\text { groundnut cultivation }\end{array}$ & 68 \\
\hline 2. Lack of HYV seed & 35 \\
\hline source. field survey, 2012
\end{tabular}

These advantages were higher profit, short duration crop, less production cost, good marketing facility and produce higher yield. A good number of groundnut farmers also wanted to increase area for the year due to meet up their household demand and for its multipurpose uses. Some groundnut farmers also mentioned various reasons for not expanding their groundnut areas for the next year. The important reasons were lack of enough land, as they need to grow other crops and lack of HYV seed.

\section{Farm level constraints to groundnut cultivation}

The sample farmers in the study areas mentioned numerous issues regarding the problems of groundnut production. Most groundnut cultivating farmers mentioned about the lack of land as a major problem. The infestation of groundnut by hairy caterpillar, stem fly was another constraint faced by many groundnut farmers. The lack of adequate technical know-how about groundnut production was also constrained some farmers to its higher production. Farmers opined that they could not attain expected yield due to these constraints (Table 7). As most of our respondents are from char areas, they face natural calamities is one of the major problems for their groundnut cultivation. About 90 percent and percent of groundnut farmers mentioned the natural calamities and lack of capital as crucial problems respectively (Table 7). 
Table 7. Problems of groundnut cultivation in the study areas

\begin{tabular}{|c|c|c|}
\hline SL.No & Type of facility & $\begin{array}{c}\text { \% of groundnut } \\
\text { farmers' responded }\end{array}$ \\
\hline 1 & Lack of capital & 82 \\
\hline 2 & Infestation of insects & 61 \\
\hline 3 & Natural calamities & 90 \\
\hline 4 & $\begin{array}{c}\text { Lack of technical know- } \\
\text { how }\end{array}$ & 63 \\
\hline 5 & Lack of land & 70 \\
\hline 6 & $\begin{array}{c}\text { Timely not available } \\
\text { human labour }\end{array}$ & 53 \\
\hline
\end{tabular}

source: field survey, 2012

\section{References}

BBS (Bangladesh Bureau of Statistics), (2009). Statistical Year Book of Bangladesh; Bangladesh Bureau of Statistics, Statistical Division, Ministry of Planning, Government of the People's Republic of Bangladesh, Dhaka.

BBS (Bangladesh Bureau of Statistics), (2011). Statistical Year Book of Bangladesh; Bangladesh Bureau of Statistics, Statistical Division, Ministry of Planning, Government of the People's Republic of Bangladesh, Dhaka

BBS (Bangladesh Bureau of Statistics), (2012). Statistical year book of Bangladesh, Bangladesh Bureau of statistics. Statistical Division, Ministry of Planning, Government of the People's Republic of Bangladesh, Dhaka.

BBS (Bangladesh Bureau of Statistics), (2014). Statistical Year Book of Bangladesh; Bangladesh Bureau of Statistics, Statistical Division, Ministry of Planning, Government of the People's Republic of Bangladesh, Dhaka.

Biswas, G. C., S. Begum and M. Y. Mian (2000). Leaf infestation and yield loss caused by thrips and jassids in groundnut. J. Asiat. Soc. Bangladesh Sci. 26 (2): 253-258.

Biswas, G. C. and G. P. Das. 2011. Insect and mite pests diversity in the oilseed crops ecosystems in Bangladesh. Bangladesh J. Zool. 39 (2): 232-235.

\section{Conclusions}

There is much empirical evidence for poverty reduction through increases in groundnut production. It is evident from the study that per acre net returns were greatly influenced by the use of human labour, animal labour, seeds and insecticides and it was found that they got profit from groundnut cultivation and the undiscounted BCRs (both the variable cost and total cost basis) was estimated at 1.88 in case of all categories of farmers. As groundnut is a profitable crop for its low cost of production, it can take part in char areas for poverty reduction. For that reason technological improvement and high yielding variety of seed is necessary for groundnut production in char areas.

Haque, f. (1993): A Comparative Economic Study Between Sweet Potato and Groundnut Specially References to Small Farmers in Some Selected Area of kishoregonj district. MS. Thesis, Bangladesh Agricultural University, Mymensingh.

Hossain, M. I., M. A. Matin and M. S. Alam (1992). Marketing of Groundnut and Soybean in Some Selected Areas of Bangladesh, Bangladesh Agricultural Research Institute, Joydebpur, Dhaka.

Krishi Diary, ( 2013). Crop production target and achieved 2011-12. Agriculture Information Service, Khamarbari, Farmgate, Dhaka. 98p.

Mondal, M. R. I. and M. A. Wahhab 2001. Production Technology of Oilcrops. Oilseed Research Centre, BARI, Gazipur, 111p.

Sabur, S. A. and M. A. M. Miah (1995): The Performance of CDP Crops Under Free Market System, Paper Presented at the $10^{\text {th }}$ National Conference of Bangladesh Agricultural Economics Association held at Bangladesh Agricultural University, Mymensingh on 27-28 April.

Varnell, R. J and D. E. Mccloud. (1975). Germplasm preservation and genotype evaluation in Arachis Internal peanut program, Gainesvilla, Florida. 29p.

Weiss, E. A. (1983). Oilseed crops. Longman group limited, New York. USA. 7p. 